UDC $616-093+547.789$

\title{
Preliminary evaluation of thiazolidinone- and pyrazoline-related heterocyclic derivatives as potential antimalarial agents
}

\author{
A. P. Kryshchyshyn-Dylevych ${ }^{1}$, N. I. Zelisko ${ }^{1}$, P. Grellier ${ }^{2}$, R. B. Lesyk ${ }^{1}$ \\ ${ }^{1}$ Danylo Halytsky Lviv National Medical University \\ 69, Pekarska Str., Lviv, Ukraine, 79010 \\ ${ }^{2}$ National Museum of Natural History, UMR 7245 CNRS MCAM, Sorbonne Universités \\ CP 52, 57 Rue Cuvier, Paris 75005, France \\ dr_r_lesyk@org.lviv.net
}

\begin{abstract}
Aim. Synthesis of a series of thiazolidinone- and pyrazoline-related compounds. In vitro screening of antiplasmodial activity of versatile heterocyclic derivatives. Methods: organic wet synthesis, analytical and spectral methods, pharmacological screening, SAR analysis. Results. A series of different thiazolidinone- and pyrazoline-based derivatives was screened against Plasmodium falciparum in in vitro assays. 5-(Z)-Arylidene-2-arylidenehydrazono-3(4-hydroxyphenyl)-4-thiazolidinones showed high growth inhibition rates with the $\mathrm{IC}_{50}-2.32$ $2.39 \mu$ M. 5-Bromo-1-[2-[3-(4-chlorophenyl)-5-(4-methoxyphenyl)-3,4-dihydropyrazol-2-yl]2-oxoethyl]indoline-2,3-dione 3 was the most active compound among tested with the $\mathrm{IC}_{50}-1.81$ $\mu \mathrm{M}$. Based on the screening data some structure-activity relationships were derived. Conclusions. A set of different thiazolidinone- and pyrazoline-related derivatives with antitrypanosomal and anticancer properties was screened against Plasmodium falciparum. Hitcompounds inhibiting growth of the parasite at micromolar concentrations were identified. The obtained results provide further avenues to develop more potent antimalarial agents on the base of investigated classes of small drug-like molecules.
\end{abstract}

Ke y w o r d s: thiazolidinone, pyrazoline, antimalarial activity, SAR analysis

\section{Introduction}

The thiazolidinone based molecules had been widely studied and described as a fruitful source of novel drug-like molecules with a variety of pharmacological profiles [1-4]. Recently, the thiazolidinone/thiazole derivatives became interesting in the field of anti- parasitic agents search [5-9]. We had designed and synthesized a class of rhodanine derivatives - 5-enamine-2-thioxo-4-thiazolidinone3 -carboxylic acids that showed [the] significant trypanocidal activity towards Trypanosoma brucei gambiense along with a good cytotoxicity profile against the myoblast derived cell line (L-6). The selectivity indices for these

(C) 2020 A. Kryshchyshyn et al.; Published by the Institute of Molecular Biology and Genetics, NAS of Ukraine on behalf of Biopolymers and Cell. This is an Open Access article distributed under the terms of the Creative Commons Attribution License (http://creativecommons.org/licenses/by/4.0/), which permits unrestricted reuse, distribution, and reproduction in any medium, provided the original work is properly cited 
compounds were within 158-1396.2 (calculated as the ratio of $\mathrm{CC}_{50}$ to $\mathrm{IC}_{50}$ ) designating this class of rhodanine-3-carboxylic acids as perspective in the search for antitrypanosomal agents [10]. For a number of related 5-benzylidenerhodanine-3-acetic acids the inhibitory activity against Trypanosoma brucei dolicholphosphate mannose synthase and glycosylphosphatidylinositol anchor was studied, these compounds also showed [the] in vitro trypanocidal activity against bloodstream forms [7]. There was also identified a row of hit-compounds among thiazolidinone/thiazoleimidazothiadiazole/phenyl-indole hybrids inhibiting growth of Trypanosoma brucei brucei and Trypanosoma gambiense at submicromolar concentrations. [11]. Encouraged by a significant trypanocidal activity of different thiazolidinone- and thiazole-based compounds we decided to study if these classes of small "drug-like molecules" possess the antimalarial activity.

Malaria is a parasitic infection of the genus Plasmodium, two of its species - Plasmodium falciparum and Plasmodium vivax account for more than $95 \%$ of clinical cases and deaths. Although, in recent years, there has been a reduction in the numbers of deaths from malaria due to the efficiency of Artemisinin combination therapies (ACTs), the latter meet new challenges because of the emerging drug resistance [12]. Traditional directions in search for new antimalarial agents usually cover the study of various artemisinin analogs as well as different aminoquinoline derivatives $[13,14]$. Despite the fact, that Artemisinin combination therapies (ACTs) play a pivotal role in malaria control programmes as they remain the cornerstone of case management, it is im- portant to develop novel classes of active agents against artemisinin resistant strains of Plasmodium ssp. as well as targeting the multiple stages of the parasite life cycle.

Among various classes of organic compounds being investigated as potential agents to treat malaria, the study of thiazole based molecules indicated this heterocycle as a pharmacophore with antimalarial properties [15]. For example, a row of aminomethylthiazole pyrazole carboxamides showed good in vitro activity against $P$. falciparum and was orally effective in a $P$. berghei mouse model [16]. 2-(2-Hydrazinyl)thiazole derivatives with 2-pyridyl moiety inhibited [the] growth of blood stage P. falciparum (NF54) in submicromolar concentrations in vitro [17].

High-throughput screening of the AstraZeneca compound library against the asexual blood stage of Plasmodium falciparum led to identification of the active amino imidazole scaffold. Optimization of the latter yielded an orally bioavailable lead - 2-aminoazabenzimidazole derivative with [the] nanomolar inhibitory activity against $P$. falciparum and efficiency in the humanized Pf/SCID model of malaria [18] (Fig. 1). The imidazolopiperazine derivatives, representing the next-generation antimalarial therapy with the clinical candidate KAF156, belong to the examples of the active antimalaria compounds bearing [6+5]-scaffolds. The latter is effective against Plasmodium falciparum drug-sensitive and drug-resistant strains in nanomolar concentrations targeting multiple life stages of the parasite like liver, ABS and gametocyte [19]. A series of tripeptides with different heterocycles in the side chains was tested for the falcipain-2 inhibitory activity as well as against Plasmodium 


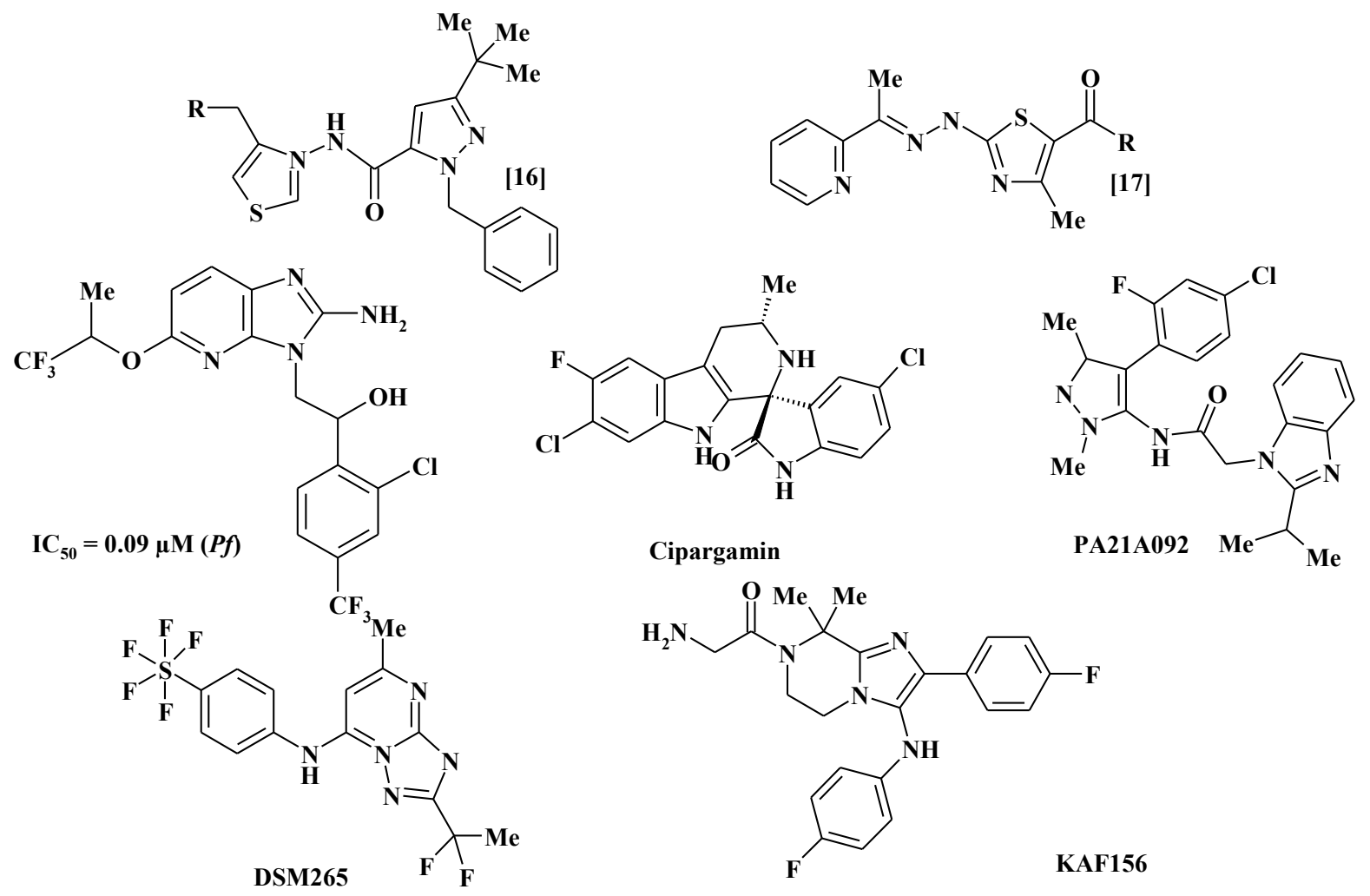

Fig.1. Examples of thiazole derivatives and different [6+5]-heterocyclic compounds active against P. falciparum.

falciparum (3D7 culture). Interestingly, the most active compounds in both assays and the less toxic contain indole fragment and different five-membered nitrogen containing heterocyclic moieties (pyrolidine and imidazole) [20].

One of the approaches to search for new antimalarials is the developing of agents with the modes of action distinct from the existing drugs. Thus, a spiroindolone derivative KAE609 (Cipargamin) is characterized by the fastest clearance rates in patients of any antimalarial yet (Fig. 1). Cipargamin targets the P-type $\mathrm{Na}^{+}$ ATPase PfATP4, affecting $\mathrm{Na}^{+}$homeostasis in the parasite and as a result blocking [the] ABS development and transmission to mosquitoes
[21]. Similar effects on intraerythrocytic Plasmodium falciparum caused a pyrazoleamide compound PA21A092 that could prevent parasite mating and therefore transmission by mosquitoes [22]. Another example of [6+5]-heterocyclic fragment implementation is an inhibitor of the mitochondrion-located DHODH (dihydroorotate dehydrogenase) DSM265 that showed the activity against both hepatic and ABS (intra-erythrocytic asexual blood stages) schizonts and was efficient even in single-dose regimens in human trials [23].

The development of novel small non-toxic molecules able to kill Leishamania and Plasmodium ssp. at different stages as well as 
to overcome multidrug resistance in treatment of the leishmaniasis and malaria is of great importance and remains a topical issue in parasitic diseases control. The attempts to develop the agents with dual inhibitory activity against both mentioned parasites had been also made. As follows, thiazolidinone and thiazole cores were utilized to obtain a series of molecules bearing thiazole/thiazolidinone cycle and pyrazole core within the hybrid pharmacophore approach. Although, pyrazolylthiosemicarbazones showed good antimalarial activity, their cyclization to thiazole and thiazolidinone increased and the hit-compounds had significant suppressive effect (>90\%) against Plasmodium berghei in in vivo assays and even showed a better activity than chloroquine phosphate against chloroquine resistant (RKL9) strain of $P$. falciparum [24].

\section{Materials and Methods}

\section{Chemistry}

All chemicals were of the analytical grade and commercially available. All reagents and solvents were used without further purification and drying. Compounds 1,2 [11], 3 [25] and 4 [26] were synthesized as described previously. NMR spectra were determined with Varian Mercury 400 (400 MHz) spectrometer, in DMSO- $d_{6}$ using tetramethylsilane as an internal standard. Elemental analyses $(\mathrm{C}, \mathrm{H}, \mathrm{N})$ were performed at the Perkin-Elmer 2400 $\mathrm{CHN}$ analyzer and were within $\pm 0.4 \%$ of the theoretical values. The melting points were measured in open capillary tubes on a BUCHI B-545 melting point apparatus and were not corrected. The purity of the compounds was checked by thin-layer chromatography per- formed with Merck Silica Gel 60 F254 aluminum sheets.

General method for synthesis of 5-(Z)arylidene-2-arylidenehydrazono-3-(4hydroxyphenyl)-4-thiazolidinones (5-7)

The mixture of 3-(4-hydroxyphenyl)thiosemicarbazide $(0.01 \mathrm{~mol})$, chloroacetic acid $(0.01 \mathrm{~mol})$, sodium acetate $(0.02 \mathrm{~mol})$ and appropriate oxocompound $(0.03 \mathrm{~mol})$ in the mixture of $5 \mathrm{~mL}$ of DMF and $10 \mathrm{~mL}$ of acetic acid was refluxed for $2 \mathrm{~h}$. After cooling, the product of the reaction was filtered off and recrystallized from the mixture of DMF-acetic acid or DMF-ethanol.

5-(Z)-[(4-Methoxyphenyl)methylene]2-[(4-methoxyphenyl)methylenehydrazono]3-(4-hydroxyphenyl)-4-thiazolidinone (5). Yield: $57 \%, \mathrm{mp}>250^{\circ} \mathrm{C},(\mathrm{DMF} / \mathrm{EtOH}) .{ }^{1} \mathrm{H}$ NMR (400 MHz, DMSO- $d_{6}$ ), $\delta$, ppm: 3.81 (s, $\left.3 \mathrm{H}, \mathrm{OCH}_{3}\right) ; 3.84\left(\mathrm{~s}, 3 \mathrm{H}, \mathrm{OCH}_{3}\right), 6.88(\mathrm{~d}, 2 \mathrm{H}$, $J=8.3 \mathrm{~Hz}$, arom.), 7.04 (d, $2 \mathrm{H}, J=8.2 \mathrm{~Hz}$, arom.), 7.15 (d, $2 \mathrm{H}, J=8.3 \mathrm{~Hz}$, arom.), 7.25 (d, $2 \mathrm{H}, J=8.3 \mathrm{~Hz}$, arom.), 7.67 (d, $2 \mathrm{H}$, $J=8.4 \mathrm{~Hz}$, arom.), 7.69 (s, $1 \mathrm{H}, \mathrm{CH}=), 7.75$ (d, $2 \mathrm{H}, J=8.3 \mathrm{~Hz}$, arom.), $8.36(\mathrm{~s}, 1 \mathrm{H}, \mathrm{CH}=\mathrm{N})$, $9.81(\mathrm{~s}, 1 \mathrm{H}, \mathrm{OH}) .{ }^{13} \mathrm{C}$ NMR $(100 \mathrm{MHz}$, DMSO- $\left.d_{6}\right), \delta$, ppm: $166.6,162.1,161.0,159.6$, $158.7,158.1,132.4,130.3,130.2,129.8,126.9$, 126.7, 126.3, 119.2, 116.0, 115.4, 114.9, 55.9, 55.9. Anal. Calcd for $\mathrm{C}_{25} \mathrm{H}_{21} \mathrm{~N}_{3} \mathrm{O}_{4} \mathrm{~S}, \%$ : C, $65.35 ; \mathrm{H}, 4.61 ; \mathrm{N}, 9.14$. Found, \%: C, 65.50; $\mathrm{H}, 4.50 ; \mathrm{N}, 9.40$.

5-(Z)-[(4-Hydroxyphenyl)methylene]2-[(4-hydroxyphenyl)methylenehydrazono]3-(4-hydroxyphenyl)-4-thiazolidinone (6). Yield: $62 \%, \mathrm{mp}>250^{\circ} \mathrm{C},(\mathrm{DMF} / \mathrm{AcOH}) .{ }^{1} \mathrm{H}$ NMR (400 MHz, DMSO- $\left.d_{6}\right), \delta$, ppm: 6.81$6.88(\mathrm{~m}, 4 \mathrm{H}, \mathrm{arom}), 6.96(\mathrm{~d}, 2 \mathrm{H}, J=7.2 \mathrm{~Hz}$, 
arom), 7.23 (d, 2H, $J=7.2 \mathrm{~Hz}$, arom.), 7.57 (d, $2 \mathrm{H}, J=7.0 \mathrm{~Hz}$, arom.), 7.63 (s, $1 \mathrm{H}, \mathrm{CH}=)$, 7.64 (d, $2 \mathrm{H}, J=8.0 \mathrm{~Hz}$, arom.), 8.29 (s, $1 \mathrm{H}$, $\mathrm{CH}=\mathrm{N}), 9.77(\mathrm{~s}, 1 \mathrm{H}, \mathrm{OH}), 10.08$ (brs, $1 \mathrm{H}$, $\mathrm{OH}), 10.24$ (s, 1H, OH). ${ }^{13} \mathrm{C}$ NMR $(100 \mathrm{MHz}$, DMSO- $\left.d_{6}\right), \delta$, ppm: $166.7,160.8,159.8,158.9$, 158.1, 132.7, 130.7, 130.4, 129.8, 129.7, 125.3, 125.1, 117.9, 116.8, 116.2, 116.1, 116.0. Anal. Calcd for $\mathrm{C}_{12} \mathrm{H}_{17} \mathrm{~N}_{3} \mathrm{O}_{4} \mathrm{~S}, \%$ : C, 64.03; H, 3.97; N, 9.74. Found, \%: C, 64.20; H, 4.00; N, 9.90.

5-(Z)-I(4-Dimethylaminohenyl) methylene]-2-[(4-dimethylaminophenyl)methylene hydrazono]-3-(4-hydroxyphenyl)-4-thiazolidinone (7). Yield: $50 \%, \mathrm{mp} 252-253^{\circ} \mathrm{C}$, (DMF/AcOH). ${ }^{1} \mathrm{H} \quad \mathrm{NMR} \quad(400 \mathrm{MHz}$, DMSO- $\left.d_{6}\right), \delta$, ppm: $2.96\left(\mathrm{~s}, 6 \mathrm{H}, 2 * \mathrm{CH}_{3}\right), 2.99$ $\left(\mathrm{s}, 3 \mathrm{H}, \mathrm{CH}_{3}\right), 3.03\left(\mathrm{~s}, 3 \mathrm{H}, \mathrm{CH}_{3}\right), 6.72(\mathrm{~d}, 2 \mathrm{H}$, $J=7.9 \mathrm{~Hz}$, arom.), 6.88 (d, $2 \mathrm{H}, J=7.8 \mathrm{~Hz}$, arom.), 7.12 (d, $2 \mathrm{H}, J=7.6 \mathrm{~Hz}$, arom.), 7.22 (d, $2 \mathrm{H}, J=7.6 \mathrm{~Hz}$, arom.), 7.54-7.60 (m, 3H, arom.), 7.62-7.64 (m, 2H, arom., $=\mathrm{CH}), 8.13$ $(\mathrm{s}, 1 \mathrm{H}, \mathrm{CH}=\mathrm{N}), 9.78(\mathrm{~s}, 1 \mathrm{H}, \mathrm{OH}),{ }^{13} \mathrm{C} \mathrm{NMR}$ (100 MHz, DMSO- $d_{6}$ ), $\delta$, ppm: $172.5,158.2$, $157.9,152.5,150.2,147.3,132.7,132.4$, 131.1, 129.9, 129.8, 129.7, 126.7, 126.4, 121.9, 116.0, 112.2, 32.5. Anal. Calcd for $\mathrm{C}_{27} \mathrm{H}_{27} \mathrm{~N}_{5} \mathrm{O}_{2} \mathrm{~S}, \%$ : $\mathrm{C}, 66.78 ; \mathrm{H}, 5.60 ; \mathrm{N}, 14.42$. Found, \%: C, $66.90 ; \mathrm{H}, 5.70 ; \mathrm{N}, 14.60$.

Synthesis of 2-I(3-(4-hydroxyphenyl)4-oxo-2-[(2-oxoindolin-3-ylidene) hydrazono] thiazolidin-5-yl]-N-(p-tolyl)acetamide (8). Equimolar amounts $(0.01 \mathrm{~mol})$ of 1-(2-oxoindolin-3-ylidene)-4-(4-hydroxyphenyl)thiosemicarbazone, ( $p$-tolyl)maleimide and acetic acid $(20 \mathrm{~mL})$ were put into round bottom flask and heated under reflux for $2 \mathrm{~h}$. After cooling the reaction mixture to room temperature, the formed precipitate was filtered off and recrystallized. Yield: $81 \%, \mathrm{mp} 212-213^{\circ} \mathrm{C},(\mathrm{DMF} /$
EtOH). ${ }^{1} \mathrm{H}$ NMR $\left(400 \mathrm{MHz}, \mathrm{DMSO}-d_{6}\right), \delta$, ppm: $2.24\left(\mathrm{~s}, 3 \mathrm{H}, \mathrm{CH}_{3}\right), 3.23\left(\mathrm{dd}, 1 \mathrm{H}, \mathrm{CH}_{2}\right.$, $J=7.6,16.8 \mathrm{~Hz}), 3.28\left(\mathrm{~m}, 1 \mathrm{H}, \mathrm{CH}_{2}\right), 4.70(\mathrm{~m}$, $1 \mathrm{H}, \mathrm{CH}), 6.68(\mathrm{t}, 1 \mathrm{H}$, arom.), $6.79(\mathrm{~d}, 2 \mathrm{H}$, $J=8.5 \mathrm{~Hz}$, arom.), 6.93-6.97 (m, 2H, arom.), 7.10 (d, 1H, $J=7.6 \mathrm{~Hz}$, arom.) 7.24-7.37 (m, 4H, arom.), $7.46(\mathrm{~d}, 1 \mathrm{H}, J=8.2 \mathrm{~Hz}$, arom.), $7.76(\mathrm{~d}, 1 \mathrm{H}, J=7.3 \mathrm{~Hz}$, arom.), 9.5 (s, $1 \mathrm{H}$, $-\mathrm{OH}), 10.63(\mathrm{~s}, 1 \mathrm{H}, \mathrm{NH}), 11.21(\mathrm{~s}, 1 \mathrm{H}, \mathrm{NH})$. ${ }^{13} \mathrm{C}$ NMR $\left(100 \mathrm{MHz}, \mathrm{DMSO}-d_{6}\right), \delta$, ppm: $176.9,174.8,167.9,163.1,158.2,156.1,142.8$, $131.7,130.2,129.6,129.5,127.8,122.8,121.7$, 120.5, 119.7, 116.0, 115.3, 111.5, 43.6, 38.8, 20.9. Anal. Calcd for $\mathrm{C}_{26} \mathrm{H}_{21} \mathrm{~N}_{5} \mathrm{O}_{4} \mathrm{~S}, \%$ : $\mathrm{C}$, 62.51; H, 4.24; N, 14.02. Found, \%: C, 62.40; $\mathrm{H}, 4.10 ; \mathrm{N}, 14.20$.

Synthesis of 9-(2-methoxyphenyl)-14-phenyl-3,7-dithia-5,14-diazapentacyclo-[9.5.1.0 $\left.{ }^{2,10} \cdot 0^{4,8} 0^{12,16}\right]$ heptadec-4(8)-ene6,13,15-trione (9). A mixture of appropriate 5-(2-methoxyphenylmethylidene)-4-thioxo2-thiazolidinone $(10 \mathrm{mmol})$ and 5-norbornene-2,3-dicarboxylic acid phenylimide (11 mmol) was refluxed for $1 \mathrm{~h}$ with a catalytic amount of hydroquinone $(2-3 \mathrm{mg}$ ) to prevent polymerization processes in $10 \mathrm{ml}$ of glacial acetic acid, and then left overnight at room temperature. The precipitated crystals were filtered off, washed with methanol $(5-10 \mathrm{ml})$, and recrystallized. Yield: $60 \%, \mathrm{mp}>250^{\circ} \mathrm{C}$ $(\mathrm{BuOH}) .{ }^{1} \mathrm{H}$ NMR (400 MHz, DMSO- $\left.d_{6}\right), \delta$, ppm: $1.70(\mathrm{~d}, 1 \mathrm{H}, J=10.0 \mathrm{~Hz}), 2.30(\mathrm{t}, 1 \mathrm{H}$, $J=8.6 \mathrm{~Hz}), 2.41(\mathrm{~d}, 1 \mathrm{H}, J=5.3 \mathrm{~Hz}), 2.52(\mathrm{~m}$, $1 \mathrm{H}), 2.71(\mathrm{~d}, 1 \mathrm{H}, J=4.9 \mathrm{~Hz}), 3.26(\mathrm{~m}, 1 \mathrm{H})$, $3.50(\mathrm{~m}, 3 \mathrm{H})$ - norbornane fragment, $\mathrm{CHAr}$; $3.74\left(\mathrm{~s}, 3 \mathrm{H}, \mathrm{OCH}_{3}\right), 6.90-7.10(\mathrm{~m}, 3 \mathrm{H}$, arom.), 7.37-7.42 (m, $2 \mathrm{H}$, arom.), 7.48-7.54 (m, $2 \mathrm{H}$, arom.), 7.62 (d, $2 \mathrm{H}, J=7.6 \mathrm{~Hz}$, arom.), 11.47 $(\mathrm{s}, 1 \mathrm{H}, \mathrm{NH}) .{ }^{13} \mathrm{C}$ NMR $\left(100 \mathrm{MHz}, \mathrm{DMSO}-d_{6}\right)$, 
$\delta, \mathrm{ppm}: 176.8,176.7,171.7,149.4,148.9$, 133.8, 133.3, 131.6, 130.1, 129.6, 121.7, 120.8, $115.7,112.9,112.2,56.0,52.6,48.9,47.6$, 45.8, 45.5, 44.9, 39.4, 38.8. Anal. Calcd for $\mathrm{C}_{26} \mathrm{H}_{22} \mathrm{~N}_{2} \mathrm{O}_{4} \mathrm{~S}_{2}, \%$ : C, 63.65; H, 4.52; N, 5.71. Found, \%: C, 65.80; H, 4.60; N, 5.60.

Synthesis of 2-(4-benzylpiperazin-1-yl)5-(3-phenylprop-2-enylidene)thiazol-4-one (10). The mixture of 2-thioxo-4-thiazolidinone $(0.01 \mathrm{~mol}), 1$-benzylpiperazine $(0.011 \mathrm{~mol})$ and cinnamaldehyde $(0.01 \mathrm{~mol})$ in $10 \mathrm{~mL}$ of ethanol is refluxed for $3 \mathrm{~h}$.

Formed precipitate is filtered off and recrystallized from 2-propanol or acetic acid.

Yield: $75 \%, \mathrm{mp} 139-141^{\circ} \mathrm{C}(i-\mathrm{PrOH}) .{ }^{1} \mathrm{H}$ NMR (400 MHz, DMSO- $\left.d_{6}\right), \delta$, ppm: 2.51$2.56\left(\mathrm{~m}, 4 \mathrm{H}, \mathrm{CH}_{2} \mathrm{CH}_{2}\right), 3.53-3.56(\mathrm{~m}, 4 \mathrm{H}$, $\left.\mathrm{CH}_{2} \mathrm{CH}_{2}\right), 3.88\left(\mathrm{~s}, 2 \mathrm{H}, \mathrm{CH}_{2} \mathrm{Ph}\right), 6.91-6.96$ (m, $1 \mathrm{H}$, arom.), 7.15-7.20 (m, 1H, arom.), 7.267.40 (m, 9H, arom.), 7.59-7.64 (m, 2H, arom.). ${ }^{13} \mathrm{C}$ NMR (100 MHz, DMSO- $\left.d_{6}\right), \delta$, ppm: 179.3, 173.6, 141.9, 138.1, 136.3, 131.5, 131.1, $129.8,129.4,128.8,127.9,127.6,125.5,61.9$, 52.4, 52.1, 48.8, 48.2. Anal. Calcd for $\mathrm{C}_{23} \mathrm{H}_{23} \mathrm{~N}_{3} \mathrm{OS}, \%$ : C, 70.92; H, 5.95; N, 10.79 . Found, \%: C, 71.00; H, 5.80; N, 10.70 .

Synthesis of 5-(Z)-(4-dimethylaminophenylmethylene)-2-(thiazol-2-yl)imino-thiazolidin-4-one (11). The mixture of 2-(thiazol2-yl)imino-4-thiazolidinone $(0.01 \mathrm{~mol})$, 4-dimethylaminobenzaldehyde $(0.015 \mathrm{~mol})$ and sodium acetate $(0.01 \mathrm{~mol})$ in $10 \mathrm{~mL}$ of acetic acid was refluxed for $3 \mathrm{~h}$. The precipitate formed after cooling the reaction mixture was filtered off and recrystallized. Yield: $73 \%, \mathrm{mp}$ $249-251{ }^{\circ} \mathrm{C}(\mathrm{AcOH}) .{ }^{1} \mathrm{H}$ NMR $(400 \mathrm{MHz}$, DMSO- $\left.d_{6}\right), \delta$, ppm: $3.12\left(\mathrm{~s}, 6 \mathrm{H}, 2 * \mathrm{CH}_{3}\right), 6.78$ (d, $2 \mathrm{H}, J=8.2 \mathrm{~Hz}$, arom.), 7.21 (d, $1 \mathrm{H}$, $J=4.6 \mathrm{~Hz}$, thiazol $), 7.46(\mathrm{~d}, 2 \mathrm{H}, J=8.2 \mathrm{~Hz}$, arom.), $7.54(\mathrm{~s}, 1 \mathrm{H}, \mathrm{CH}=), 7.64(\mathrm{~d}, 1 \mathrm{H}, J=4.7$ $\mathrm{Hz}$, thiazol), 12.10 (s, 1H, NH). ${ }^{13} \mathrm{C}$ NMR (100 MHz, DMSO- $\left.d_{6}\right), \delta$, ppm: 173.8, 164.9, 152.4, 146.6, 141.3, 134.1, 133.3, 122.5, 121.2, 117.9, 113.2, 36.7. Anal. Calcd for $\mathrm{C}_{15} \mathrm{H}_{14} \mathrm{~N}_{4} \mathrm{OS}_{2}, \%$ : C, 54.52; H, 4.27; N, 16.96. Found, \%: C, $54.60 ; \mathrm{H}, 4.30 ; \mathrm{N}, 16.70$.

\section{Pharmacology}

Antimalarial activity assay. P. falciparum strain FcB1/colombia was maintained continuously in culture on human erythrocytes as described by Trager and Jensen [27]. [The] In vitro antiplasmodial activity was determined using a modification of the semi-automated microdilution technique [28]. Chloroquine diphosphate was used as a reference drug. Stock solutions of chloroquine diphosphate and test compounds were prepared in sterile, distilled water and DMSO, respectively. Drug solutions were serially diluted with the culture medium and added to asynchronous parasite cultures $(1 \%$ parasitemia and $1 \%$ final hematocrite) in 96-well plates for $24 \mathrm{~h}$, at $37^{\circ} \mathrm{C}$, prior to the addition of $0.5 \mathrm{ACi}$ of [3H]hypoxanthine ( 1 to $5 \mathrm{Ci} / \mathrm{mmol}$; Amersham, Les Ulis, France) per well, for $24 \mathrm{~h}$. The growth inhibition for each drug concentration was determined by comparison of the radioactivity incorporated into the treated culture with that in the control culture (without drug) maintained on the same plate. The concentration causing $50 \%$ inhibition $\left(\mathrm{IC}_{50}\right)$ was obtained from the drug concentration-response curve and the results were expressed as the mean of the standard deviations determined from several independent experiments. The DMSO concentration never exceeded $0.1 \%$ and did not inhibit the parasite growth. 


\section{Results and Discusion}

Taking into account high antitrypanosomal activity of some groups of thiazolidinone derivatives, we intended to study possible antimalarial activity of some thiazolidinones. Different 4-thiazolidinone- and pyrazolinebased compounds from our in-home library [1] were investigated in the in vitro study against Plasmodium falciparum at the concentration of $10 \mu \mathrm{g} / \mathrm{mL} .11$ derivatives out of 40 studied ones inhibited growth of the parasites by more than $80 \%$ (Table 1); for these hit-compounds the $\mathrm{IC}_{50}$ values were estimated. Compounds 1 and $\mathbf{2}$ were selected from a series studied in the antitrypanosomal assays [11]; 5-bromo-1[ 2 - [ 3 - ( 4 - c h 1 oro ph e n y 1$)-5$ - ( 4 methoxyphenyl)-3,4-dihydropyrazol-2-yl]2-oxo-ethyl]indoline-2,3-dione 3 was synthe-

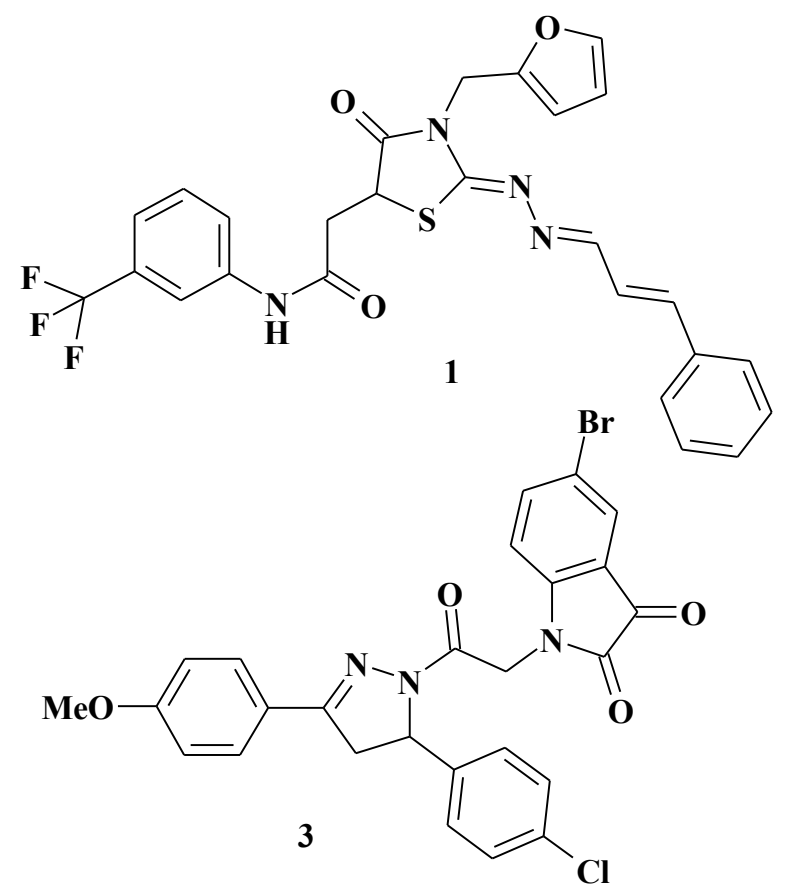

sized as described elsewhere [25] as well as 5-(4-hydroxy-3,5-dimethoxybenzylidene)-2[5-(2-hydroxyphenyl)-3-phenyl-4,5-dihydro$1 H$-pyrazol-1-yl]-1,3-thiazol-4(5H)-one 4 was synthesized according to the known method [26] (Fig. 2).

5-(Z)-Arylidene-2-arylidenehydrazono-3(4-hydroxyphenyl)-4-thiazolidinones 5-7 were synthesized in the one-step modified Knoevenagel reaction of 4-(4-hydroxyphenyl) thiosemicarbazide with appropriate aromatic aldehydes and chloroacetic acid in the acetic acid medium in the presence of sodium acetate. Compound 8 was obtained following the reaction of 1-(2-oxoindolin-3-ylidene)-4-(4-hydroxyphenyl)thiosemicarbazone with ( $p$-tolyl) maleimide in the glacial acetic acid medium (Scheme 1).
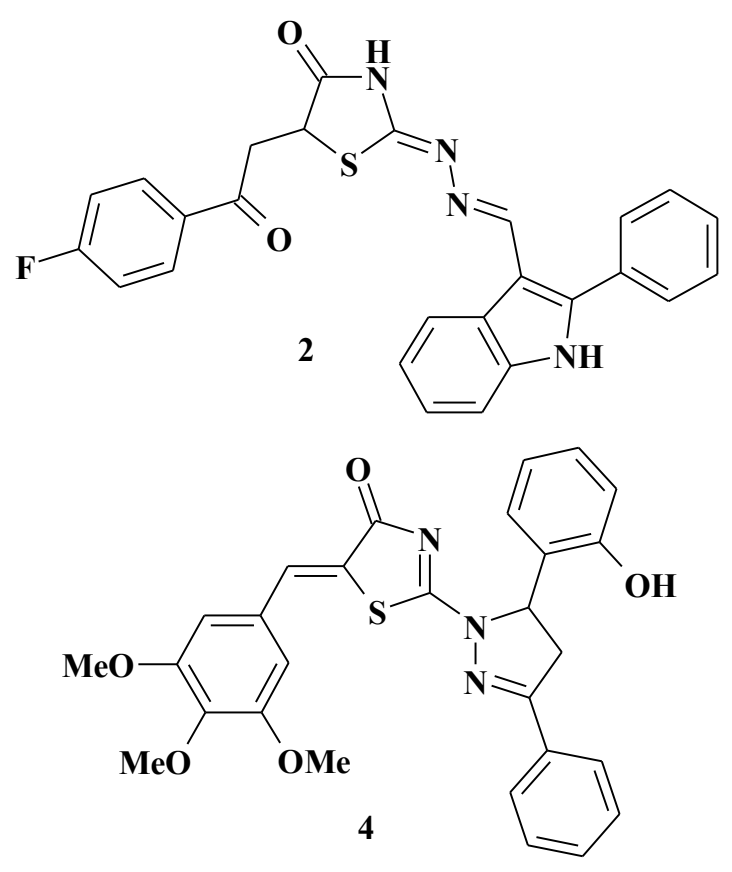

Fig. 2. The selected compounds resynthesized for antiplasmodium assay. 
<smiles>NNC(=S)Nc1ccc(O)cc1</smiles><smiles>[R]c1ccc(C=O)cc1</smiles><smiles>[R]c1ccc(/C=C2\S/C(=N\N=C\c3ccc([R])cc3)N(c3ccc(O)cc3)C2=O)cc1</smiles>

5. $\mathrm{R}=\mathrm{OMe}$

6. $\mathrm{R}=\mathrm{OH}$

7. $\mathrm{R}=\mathrm{NMe}_{2}$<smiles>O=C1Nc2ccccc2/C1=N/NC(=S)Nc1ccc(O)cc1</smiles><smiles>CC(C)=CCC(=O)O</smiles><smiles>O=C(CC1S/C(=N\N=C2/C(=O)Nc3ccccc32)N(c2ccc(O)cc2)C1=O)Nc1ccccc1</smiles>

Scheme 1. General scheme of the 5-substituted 2-arylidenehydrazono-3-(4-hydroxyphenyl)-4-thiazolidinones synthesis.

3,7 - Dithia- 5,14 - diazapentacyc $\operatorname{lo}\left[9 \cdot 5 \cdot 1 \cdot 0^{2,10} \cdot 0^{4,8} \cdot 0^{12,16}\right]$ heptadecene 9 was synthesized in the hetero-Diels-Alder reaction of 5-norbornene-2,3-dicarboxylic acid phenylimide and 5-(2-methoxybenzylidene)-4-thioxo2-thiazolidinone in glacial acetic acid with adding a catalytic amount of hydroquinone to inhibit a side polymerization reaction (Scheme 2).

2-(4-Benzylpiperazin-1-y1)-5-(3phenylprop-2-enylidene)thiazol-4-one 10 was synthesized in the one-pot three-component reaction of the rhodanine, cynnamaldehyde and 1-benzylpiperazine (Scheme 3).

Compound 11 was synthesized in the two step synthetic protocol via formation of 2-(thiazol-2-yl)imino-4-thiazolidinone in the reaction of appropriate chloroacetamide with ammonium rhodanide and acetone and further Knoevenagel condensation (Scheme 4).

In general, all tested compounds possessed moderate and good antiplasmodial properties, although, it is rather complicated to outline any structure-activity peculiarities as the hit- 


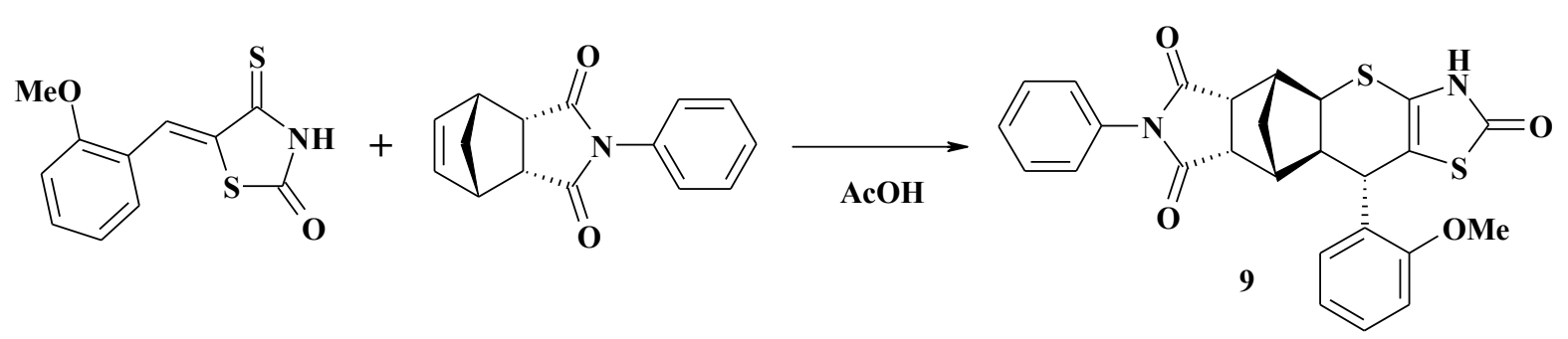

Scheme 2. Synthesis of 9-(2-methoxyphenyl)-14-phenyl-3,7-dithia-5,14-diazapentacyclo- $\left[9 \cdot 5 \cdot 1 \cdot 0^{2,10} \cdot 0^{4,8} \cdot 0^{12,16}\right]$ heptadec-4(8)-ene-6,13,15-trione 9.<smiles>O=CC=Cc1ccccc1</smiles>

Scheme 3. Synthesis 2-(4-benzylpiperazin-1-yl)-5-arylidene-thiazol-4-one $\mathbf{1 0 .}$

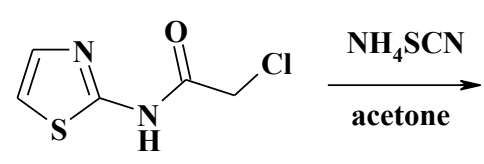<smiles>O=C1CS/C(=N/c2nccs2)N1</smiles><smiles>CN(C)c1ccc(/C=C2\S/C(=N/c3nccs3)NC2=O)cc1</smiles>

Scheme 4. Synthesis of 5-(Z)-(4-dimethylaminophenylmethylene)-2-(thiazol-2-yl)imino-thiazolidin-4-one 11.

compounds selected in antimalarial primary assays are represented by different classes of thiazolidinone- and pyrazoline-based compounds. The best inhibition activity towards Plasmodium falciparum was observed for 5-(Z)-arylidene-2-arylidenehydrazono-3-(4hydroxyphenyl)-4-thiazolidinones 5, 6 and pyrazoline derivative $\mathbf{3}$. In general, all studied groups of thiazolidinone-based compounds showed significant Plasmodium growth inhibition in the concentration of $10 \mu \mathrm{M} / \mathrm{mL}$, although the calculated $\mathrm{IC}_{50}$ values were within
1.81-13.29 $\mu \mathrm{M}$. The $\mathrm{IC}_{50}$ of 5-bromo-1-[2-[3(4-chlorophenyl)-5-(4-methoxyphenyl)-3,4dihydropyrazol-2-yl]-2-oxo-ethyl]indoline-2,3dione 3 was one of the lowest among all tested compounds $(1.81 \mu \mathrm{M})$. This pyrazoline containing molecule was also highly effective in the anticancer activity assay; at the micromolar concentrations it inhibited the growth of majority of the tested cancer cell lines and moreover showed certain selectivity towards Leukemia panel [25]. Such a promiscuous behaviour makes it a promising object within 
the concepts of polypharmacological approach and multitarget drugs design [29-33]. The studied 5-( $Z$ )-arylidene-2-arylidenehydrazono-3(4-hydroxyphenyl)-4-thiazolidinones 5-7 were characterized by the comparable $\mathrm{IC}_{50}$ values proving [a] positive impact of combination of thiazolidinone core and hydrazine moiety on the antiparasitic activity [6]. On the other hand, such an impact strongly depends on other fragments in the molecule, e.g. the compond 1 bearing also a cinnamoyl fragment did not show high antimalarial activity. Interestingly, the compounds $\mathbf{1}$ and $\mathbf{2}$ earlier tested against Trypanosoma brucei brucei [11] showed analogous results regarding the antiplasmodial activity levels: i) compound $\mathbf{1}$ inhibited the growth of Trypanosoma brucei brucei by more than $90 \%$ (by $83 \%$ for Plasmodium falciparum) and was not active at $1 \mu \mathrm{g} / \mathrm{mL}$; ii) the $\mathrm{IC}_{50}$ calculated for compound 2 was $10.63 \mu \mathrm{M}$ (comparing to $5.31 \mu \mathrm{M}$ calculated in antimalarial assay). 3,7-Dithia-5,14-diazapentacyc $\operatorname{lo}\left[9 \cdot 5 \cdot 1 \cdot 0^{2,10} \cdot 0^{4,8} \cdot 0^{12,16}\right]$ heptadecene 9 was cho-

Table 1. Antimalarial activity of studied heterocyclic derivatives

\begin{tabular}{l|l|l|c}
\hline Compound & $\begin{array}{c}\text { Inhibition, } \mathbf{\%} \\
(\mathbf{1 0} \boldsymbol{\mu g} / \mathbf{m L})\end{array}$ & $\mathbf{I C}_{50} \boldsymbol{\mu g} / \mathbf{m l}$ & $\mathbf{I C}_{50}, \boldsymbol{\mu M}$ \\
\hline $\mathbf{1}$ & 83.00 & $7.00 \pm 0.40$ & $13.29 \pm 0.76$ \\
\hline $\mathbf{2}$ & 82.19 & $2.50 \pm 0.60$ & $5.31 \pm 1.28$ \\
\hline $\mathbf{3}$ & 96.40 & $1.00 \pm 0.10$ & $1.81 \pm 0.18$ \\
\hline $\mathbf{4}$ & 88.15 & $4.50 \pm 0.30$ & $8.97 \pm 0.60$ \\
\hline $\mathbf{5}$ & 82.19 & $1.10 \pm 0.10$ & $2.39 \pm 0.22$ \\
\hline $\mathbf{6}$ & 96.00 & $1.00 \pm 0.10$ & $2.32 \pm 0.23$ \\
\hline $\mathbf{7}$ & 83.07 & $1.70 \pm 0.10$ & $3.50 \pm 0.21$ \\
\hline $\mathbf{8}$ & 83.77 & $3.50 \pm 0.10$ & $7.01 \pm 0.20$ \\
\hline $\mathbf{9}$ & 85.64 & $2.10 \pm 0.10$ & $4.28 \pm 0.20$ \\
\hline $\mathbf{1 0}$ & 96.40 & $2.70 \pm 0.20$ & $6.93 \pm 0.51$ \\
\hline $\mathbf{1 1}$ & 92.56 & $2.00 \pm 0.10$ & $6.05 \pm 0.30$ \\
\hline Chloro- & & & $0.065 \pm 0.001$ \\
$\mathbf{q u i n e}$ & & & \\
\hline
\end{tabular}

sen for the screening as an example of fused thiopyranothiazole scaffold that retains pharmacological profile of its precursors - 5-ene4-thiazolidinones, but at the same time does not keep the undesirable Michael acceptor properties [29]. Indeed, compound 9 showed a high rate of parasites growth inhibition at the concentration of $10 \mu \mathrm{g} / \mathrm{mL}$ and the $\mathrm{IC}_{50}$ value comparable with that for other derivatives.

Conclusions. A versatile row of thiazolidinone and pyrazoline derivatives was studied against Plasmodium falciparum in the in vitro assay. The calculated $\mathrm{IC}_{50}$ values were within 1.81-13.29 $\mu \mathrm{M}$ indicating the suitability of the described class of small molecules for the purposes of medicinal chemistry. For some of the investigated compounds a significant trypanocidal activity against Trypanosoma brucei brucei and Trypanosoma gambiense had been earlier established that can warrant the in-depth study of the above-mentioned molecules as promising antiparasitic agents.

\section{REFERENCES}

1. Lesyk R, Zimenkovsky B, Kaminskyy D, Kryshchyshyn A, Havryluk D, Atamanyuk D, Subtel'na I, Khyluk $D$. Thiazolidinone motif in anticancer drug discovery. Experience of DH LNMU medicinal chemistry scientific group. Biopolym Cell. 2011; 27(2):107-117.

2. Kaminskyy D, Kryshchyshyn A, Lesyk R. 5-Ene4-thiazolidinones e an efficient tool in medicinal chemistry, Eur J Med Chem. 2017; 140:542-594.

3. Kaminskyy D, Kryshchyshyn A, Lesyk R. Recent developments with rhodanine as a scaffold for drug discovery. Expert Opin Drug Discov. 2017; 12:1233-1252.

4. Kaminskyy D, Subtel'na I, Zimenkovsky B, Karpenko O, Gzella A, Lesyk R. Synthesis and evaluation of anticancer activity of 5-ylidene-4-aminothiazol2(5H)-one derivatives. Med Chem. 2015; 11:517-530. 
5. Lima Leite A, de M. Moreira D, de O. Cardoso $M$, Hernandes $M$, Alves Pereira V, Silva R, Kiperstok $A$, da S. Lima $M$, Soares $M$. Synthesis, cruzain docking, and in vitro studies of aryl-4-oxothiazolylhydrazones against trypanosoma cruzi, Chem Med Chem: Chemistry Enabling Drug Discovery. 2007; 2(9):1339-1345.

6. Kryshchyshyn A, Kaminskyy D, Grellier P, Lesyk R. Trends in research of antitrypanosomal agents among synthetic heterocycles, Eur J Med Chem. 2014; 85:51-64.

7. Smith T, Young B, Denton H, Hughes D, Wagner G. First small molecular inhibitors of T. brucei dolicholphosphate mannose synthase (DPMS), a validated drug target in African sleeping sickness. Bioorg Med Chem Lett. 2009; 19:1749-1752.

8. Havrylyuk D, Zimenkovsky B, Vasylenko O, Day C, Smee D, Grellier P, Lesyk R. Synthesis and biological activity evaluation of 5-pyrazoline substituted 4-thiazolidinones. Eur J Med Chem. 2013; 66:228-237.

9. Havrylyuk D, Zimenkovsky B, Karpenko O, Grellier $P$, Lesyk $R$. Synthesis of pyrazoline-thiazolidinone hybrids with trypanocidal activity. Eur J Med Chem. 2014; 85:245-254.

10. Holota S, Kryshchyshyn A, Derkach H, Trufin $Y$, Demchuk I, Gzella A, Grellier P, Lesyk, R. Synthesis of 5-enamine-4-thiazolidinone derivatives with trypanocidal and anticancer activity. Bioorg Chem. 2019; 86:126-136.

11. Kryshchyshyn A, Kaminskyy D, Karpenko O, Gzella A, Grellier P, Lesyk R. Thiazolidinone/thiazole based hybrids - New class of antitrypanosomal agents. Eur J Med Chem. 2019; 174:292-308.

12. Blasco B, Leroy D, Fidock D. Antimalarial drug resistance: linking Plasmodium falciparum parasite biology to the clinic. Nat Med. 2017; 23(8):917.

13. Sharma $M$, Chauhan $K$, Srivastava $R$, Singh $S$, Srivastava K, Saxena J, Sunil K, Chauhan P. Design and synthesis of a new class of 4-aminoquinolinyland 9-anilinoacridinyl schiff base hydrazones as potent antimalarial agents. Chem Biol Drug Des. 2014; 84(2):175-181

14. Burrows J, Burlot E, Campo B, Cherbuin S, Jeanneret $S$, Leroy D, Spangenberg T, Waterson D,
Wells T, Willis, P. Antimalarial drug discovery-the path towards eradication. Parasitology. 2014; 141(1):128-139.

15. Branowska D, Farahat A, Kumar A, Wenzler $T$, Brun R, Liu Y,Wilson D, Boykin D. Synthesis and antiprotozoal activity of 2,5-bis[amidinoaryl]thiazoles. Bioorg Med Chem. 2010; 18(10):3551-3558.

16. González D, Douelle D, Feng T, Nchinda A, Younis Ya, White K, Wu Q, Ryan E, Burrows J, Waterson D, Witty $M$, Wittlin $S$, Charman $S$, Chiballe $K$. Novel orally active antimalarial thiazoles. $J$ Med Chem. 2011; 54(21):7713-7719.

17. Makam $P$, Thakur $P$, Kannan, $T$. In vitro and in silico antimalarial activity of 2-(2-hydrazinyl) thiazole derivatives. Eur J Pharm Sci. 2014; 52:138-145.

18. Hameed P, Chinnapattu $M$, Shanbag $G$, Manjrekar $P$, Koushik K, Raichurkar A, Patil V, Jatheendranath $S$, Rudrapatna S, Barde $S$, Rautela N, Awasthy D, Morayya $S$, Narayan $C$, Kavanagh $S$, Saralaya $R$, Bharath S, Viswanath P, Mukherjee K, Bandodkar B, Srivastava A, Panduga $V$, Reddy J, Prabhakar K, Sinha A, Jiménez-Díaz M, Martínez M, AnguloBarturen I, Ferrer S, Sanz L, Gamo F, Duffy $S$, Avery V, Pamela A, Magistrado P, Lukens A, Wirth D, Waterson D, Balasubramanian V, Iyer P, Shridhar N, Hosagrahara $V$, Sambandamurthy $V$, Ramachandran $S$. Aminoazabenzimidazoles, a novel class of orally active antimalarial agents. J Med Chem. 2014; 57(13):5702-5713.

19. Kuhen K, Chatterjee A, Rottmann M, Gagaring K, Borboa R, Buenviaje J, Chen Zh, a Francek $C$, Wu T, Nagle A, Barnes $W$, Plouffe D, Lee M, Fidock D, Graumans $W$, Vegte-Bolmer $M$, van Gemert $G$, Wirjanata $G$, Sebayang B, Marfurt J, Russell B, Suwanarusk $R$, Price $R$, Nosten F, Tungtaeng A, Gettayacamin M, Sattabongkot J,n,k Taylor J, Walker J, Tully D, Patra K, Flannery E, Vinetz J, Renia L, Sauerwein R, Winzeler E, Glynne R, Diagana $T$. KAF156 is an antimalarial clinical candidate with potential for use in prophylaxis, treatment, and prevention of disease transmission. Antimicrob Agents Chemother. 2014; 58:5060-5067.

20. Chakka S, Kalamuddin M, Sundararaman $S$, Wei L, Mundra S, Mahesh R, Malhotra P, Mohmmed A, 
Kotra L. Identification of novel class of falcipain-2 inhibitors as potential antimalarial agents. Bioorg Med Chem. 2015; 23(9):2221-2240.

21. White N, Pukrittayakamee S, Phyo A, Rueangweerayut $R$, Nosten $F$, Jittamala P, Jeeyapant A, Jain J, Lefèvre G, Li R, Magnusson B, Diagana T, Leong J. Spiroindolone KAE609 for falciparum and vivax malaria. N Engl J Med. 2014; 371:403-410.

22. Vaidya A, Morrisey J, Zhang Zh, Das S, Daly T, Otto T, Spillman N, Wyvratt M, Siegl P, Marfurt J, Wirjanata $G$, Sebayang B, Price R, Chatterjee A, Nagle A, Stasiak M, Charman S, Angulo-Barturen I, Ferrer S, Jiménez-Díaz M, Martínez M, Gamo F, Avery V, Ruecker A, Delves $M$, Kirk K, Berriman M, Kortagere S, Burrows J, Fan E, Bergman L. Pyrazoleamide compounds are potent antimalarials that target $\mathrm{Na}+$ homeostasis in intraerythrocytic Plasmodium falciparum. Nat Commun. 2014; 5:5521.

23. McCarthy J, Lotharius J, Rückle T, Chalon S, Phillips $M$, Elliott S, Sekuloski S, Griffin P, $\mathrm{Ng} \mathrm{C,} \mathrm{Fi-}$ dock D, Marquart L, Williams N, Gobeau N, Bebrevska L, Rosario M, Marsh K, Möhrle J. Safety, tolerability, pharmacokinetics, and activity of the novel long-acting antimalarial DSM265: a two-part first-in-human phase 1a/1b randomised study. Lancet Infect Dis. 2017; 17:626-635.

24. Bekhit A, Hassan A, El Razik H, El-Miligy M, ElAgroudy E, Bekhit A. New heterocyclic hybrids of pyrazole and its bioisosteres: design, synthesis and biological evaluation as dual acting antimalarialantileishmanial agents. Eur J Med Chem. 2015; 94:30-44.

25. Havrylyuk D, Kovach N, Zimenkovsky B, Vasylenko $O$, Lesyk $R$. Synthesis and anticancer activity of isatin-based pyrazolines and thiazolidines conjugates. Arch Pharm. 2011; 344(8):514-522.

26. Havrylyuk D, Zimenkovsky B, Vasylenko O, Zaprutko L, Gzella A, Lesyk R. Synthesis of novel thiazolone-based compounds containing pyrazoline moiety and evaluation of their anticancer activity. Eur J Med Chem. 2009; 44(4):1396-1404.

27. Trager $W$, Jensen $J$. Human malaria parasites in continuous culture. Science. 1976; 193(4254):673-675.

28. Desjardins R, Canfield C, Haynes J, Chulay J. Quantitative assessment of antimalarial activity in vitro by a semiautomated microdilution technique. Antimicrob Agents Chemother. 1979; 16(6):710-718.

29. Kryshchyshyn A, Atamanyuk D, Kaminskyy D, Grellier $P$, Lesyk $R$. Investigation of anticancer and antiparasitic activity of thiopyrano[2,3-d]thiazoles bearing norbornane moiety. Biopolym Cell. 2017; 33(3): 183-205.

30. Kaminskyy D, Kryshchyshyn A, Nektegayev I, Vasylenko O, Grellier P, Lesyk R. Isothiocoumarin-3-carboxylic acid derivatives: Synthesis, anticancer and antitrypanosomal activity evaluation. Eur $\mathrm{J} \mathrm{Med}$ Chem. 2014; 75:57-66.

31. Kryshchyshyn A, Kaminskyy D, Nektegayev I, Grellier P, Lesyk R. Isothiochromenothiazoles - A class of fused thiazolidinone derivatives with established anticancer activity that inhibits growth of Trypanosoma brucei brucei. Sci Pharm. 2018; 86(4):47.

32. de Siqueira L, de Moraes $G$, de Lima Ferreira L, de Melo Rego M, Leite A. Multi-target compounds acting in cancer progression: focus on thiosemicarbazone, thiazole and thiazolidinone analogues. Eur J Med Chem. 2019; 170:237-260.

33. Bolognesi M, Cavalli A. Multitarget drug discovery and polypharmacology. Chem Med Chem. 2016; 11(12):1190-1192.

\section{Попередня оцінка гетероциклічних похідних тіазолідинону та піразоліну як потенційних протималярійних агентів}

А. П. Крищишин-Дилевич, Н. І. Зеліско, Ф. Грельє, Р. Б. Лесик

Мета. Синтез ряду похідних тіазолідинону та піразоліну. In vitro скринінг протималярійної активності різноманітних гетероциклічних похідних на їх основі. Методи: органічний синтез, аналітичні та спектральні методи, фармакологічний скринінг, аналіз взаємозв'язку структура-активність. Результати: Проведено in vitro дослідження інгібування росту Plasmodium falciparum різноманітними похідними тіазолідинону та піразоліну. 5-(Z)-Ариліден-2ариліденгідразоно-3-(4-гідроксифеніл)-4-тіазолідинони володіли високою антиплазмодійною активністю із показниками напівмаксимальних інгібуючих концен- 
трацій $\mathrm{IC}_{50}-2.32-2.39$ мкМ. Найактивнішою сполукою серед досліджуваних виявився 5-бромо-1-[2-[3-(4хлорофеніл)-5-(4-метоксифеніл)-3,4-дигідропіразол-2іл]-2-оксоетил]індолін-2,3-діон ( $\mathrm{IC}_{50}-1.81$ мкМ). Результати скринігу дозволили окреслити деякі закономірності взаємозв'язку структура-активність. Висновки. Ряд структурно різноманітних похідних тіазолідинону та піразоліну із раніше встановленими протитрипаносомною та протипухлинною активністю були дослідженні у тесті на Plasmodium falciparum. Виявлено сполуки-хіти, що інгібували ріст збудника малярії у мікромолярних концентраціях. Отримані результати забезпечують подальші шляхи розробки потенційних протималярійних агентів на основі досліджених класів малих «лікоподібних» молекул.

Кл юч о в і с л о в а: тіазолідинон, піразолін, протималярійна активність, аналіз структура-активність.

\section{Предварительная оценка гетероциклических производных тиазолидинона и пиразолина как потенциальных противомалярийных агентов}
А. П. Крищишин-Дилевич, Н. И. Зелиско, Ф. Грелье, Р. Б. Лесык

Цель. Синтез ряда производных тиазолидинона и пиразолина. In vitro скрининг противомалярийной активности различных гетероциклических производных на их основе. Методы: органический синтез, аналитические и спектральные методы, фармакологи- ческий скрининг, анализ взаимосвязи структура-активность. Результаты. Проведено in vitro исследования ингибирования роста Plasmodium falciparum различными производными тиазолидинона и пиразолина. 5-(Z)-Арилиден-2-арилиденгидразоно-3-(4гидроксифенил)-4-тиазолидиноны обладали высокой антиплазмодийной активностью с показателями полумаксимальных ингибирующих концентраций $\mathrm{IC}_{50}$ 2.32-2.39 мкМ. Самым активным соединением среди исследуемых оказался 5-бром-1-[2- [3-(4-хлорофенил)-5-(4-метоксифенил)-3,4-дигидропиразол-2-ил]-2-оксоетил]-индолин-2,3-дион ( $\mathrm{IC}_{50}-1.81$ мкМ). Результаты скрининга позволили очертить некоторые закономерности взаимосвязи структура-активность. Выводы. Ряд структурно различных производных тиазолидинона и пиразолина с ранее установленными противотрипаносомной и противоопухолевой активностью были исследованы в тесте на Plasmodium falciparum. Выявлены соединения-хиты, что ингибировали рост возбудителя малярии в микромолярных концентрациях. Полученные результаты обеспечивают дальнейшие пути разработки потенциальных противомалярийных агентов на основе исследованных классов малых «drug-like» молекул.

Кл юч е в ы е с л о в а: тиазолидинон, пиразолин, противомалярийная активность, анализ структура-активность. 